\title{
PELAKSANAAN PERJANJIAN KERJASAMA OPERASI (KSO) ANTARA PT. GARUDA INDONESIA TBK DAN PT. SRIWIJAYA GROUP DALAM PERSPEKTIF HUKUM ANTI MONOPOLI DAN PERSAINGAN USAHA TIDAK SEHAT
}

\author{
Ratih Kemala \\ Program Magister Hukum Universitas Indonesia \\ Jalan Salemba No. 5 Jakarta Pusat \\ kemala.ratih@gmail.com
}

Naskah diterima : 15/05/2019, revisi : 16/06/2019, disetujui 17/06/2019

\begin{abstract}
ABSTRAK
Undang-undang No. 5 Tahun 1999 tentang Larangan Praktek Monopoli dan Persaingan Usaha Tidak Sehat merupakan salah satu Power of Economic Regulation, yaitu kekuasaaan pemerintah untuk mengelola pasar yang di dalamnya meliputi Komisi Pengawas Persaingan Usaha (KPPU) sebagai suatu lembaga yang diberi kewenangan untuk melakukan penilaian terhadap aktifitas pelaku usaha di Indonesia. Termasuk pelaku usaha di bidang penerbangan sipil, yang saat ini mendapat sorotan dikarenakan harga tarif tiket pesawat yang mengalami kenaikan dari 40\% hingga 120\% bersamaan dengan setelah dilakukannya Perjanjian Kerjasama Operasi (KSO) antara Garuda dan Sriwijaya. Atas dasar penyelidikan yang dilakukan oleh KPPU terhadap kedua maskapai tersebut, penulis melakukan penelitian yang serupa mengenai indikasi kartel dan rangkap jabatan (Cross Ownership) antara kedua maskapai. Penulis mendapatkan tidak terjadi kartel dalam perjanjian kedua maskapai namun adanya permasalahan operasional yang menyulitkan maskapai untuk tetap bertahan dengan harga tarif sebelumnya. Meskipun begitu harga tarif yang dinaikan ternyata tidak menyalahi batas maksimum tarif angkitan udara yang ditetapkan pemerintah. Sementara fakta rangkap jabatan memang terjadi antara kedua maskapai namun sampai saat ini KPPU belum melakukan publikasi dan klarifikasi mengenai masalah ini.
\end{abstract}

Kata Kunci: Tiket pesawat, Kartel, Rangkap jabatan, Garuda, Sriwijaya

\section{PENDAHULUAN}

\section{A. Latar Belakang}

Hubungan antara transportasi udara dan aktivitas perekonomian merupakan suatu hal yang kompleks. Selama beberapa dekade terakhir, penggunaan transportasi 
udara dan aktivitas perekonomian telah berkembang di seluruh dunia. ${ }^{1}$ Pertumbuhan sektor transportasi udara akan mencerminkan pertumbuhan ekonomi secara langsung sehingga transportasi mempunyai peranan yang penting dan strategis, baik secara makro maupun mikro. ${ }^{2}$

Keberhasilan sektor transportasi udara secara makro diukur dari sumbangan nilai tambahnya dalam pembentukan Produk Domestik Bruto (PDB), dampak ganda (multiplier effect) yang ditimbulkannya terhadap pertumbuhan sektor-sektor lain dan kemampuannya meredam laju inflasi melalui kelancaran distribusi barang dan jasa ke seluruh pelosok tanah air. Sedangkan dari aspek mikro, keberhasilan sektor transportasi diukur dari kapasitas yang tersedia, kualitas pelayanan, keselamatan, aksesibilitas, keterjangkauan daya beli masyarakat dan utilisasi. ${ }^{3}$

Pada tingkat pertumbuhan ekonomi yang relatif rendah dengan tingkat penggerakan masyarakat yang juga rendah, penyelenggaraan transportasi khususnya transportasi udara bukan merupakan kegiatan usaha yang mendatangkan keuntung bagi penyelenggarannya, tetapi tetap harus dilaksanakan untuk menjamin adanya pertumbuhan ekonomi di suatu wilayah indonesia. ${ }^{4}$

Dalam butir Pasal 33 UUD 1945 yang merupakan sendi utama bagi perekonomian dan politik sosial Republik Indonesia, ${ }^{5}$ menyatakan bahwa cabangcabang produksi yang penting bagi negara dan yang menguasai hajat hidup orang banyak dikuasai oleh Negara, ${ }^{6}$ serta perekonomian nasional diselenggarakan berdasar atas demokrasi ekonomi dengan prinsip kebersamaan, efisiensi berkeadilan, berkelanjutan, berwawasan lingkungan, kemandirian, serta dengan menjaga keseimbangan kemajuan dan kesatuan ekonomi nasional.7 Maka sektor transportasi

1 Tito Tusmar dan Minda Mora, Warta Ardhia, "Perkembangan Perekonomian Wilayah dan Kargo Udara: Korelasi atau Kausalitas?” Jurnal Pusat Litbang Perhubungan Udara Vol. 41 No. 1 hal. 39-48 (2015).

2 Menurut Agus Santoso, Mantan Menteri Perhubungan RI, saat menjadi pembicara kunci pada acara Expert Talk: Aviation Industri di Hotel Margo, Depok. Acara yang diadakan oleh Himpunan Mahasiswa Teknik Industri Universitas Indonesia ini dalam rangka Industrial and Systems Engineering Competition (ISEEC) 2018, tersedia di: https://www.suaramerdeka.com/news/baca/24547/pertumbuhan-sektor-transportasi-udaracerminkan-ekonomi-nasional. Di akses pada 3 Maret 2019.

3 Ibid,

${ }^{4}$ Departemen Perhubungan R.I. (2005). Cetak Biru Transportasi Udara 2005-2024. Direktorat Jenderal Perhubungan Udara, Jakarta

5 Mohammad Hatta, Pengertian Pancasila, (Jakarta: Idayu, 1981), Hal. 36.

${ }^{6}$ Republik Indonesia, Undang-Undang Dasar Republik Indonesia dan Perubahannya, pasal 33 butir 1.

${ }^{7}$ Ibid, butir 3 . 
haruslah memiliki Power of Economic Regulation, yaitu kekuasaaan pemerintah untuk mengelola pasar. ${ }^{8}$

Untuk maksud tersebut pada tanggal 5 Maret 1999 telah diundangkan Undangundang Nomor 5 Tahun 1999 tentang Larangan Praktek Monopoli dan Persaingan Usaha Tidak Sehat. Yang mana tindakan-tindakan yang berhubungan dengan pasar sekaligus sebagai ruang lingkup undang-undang ini adalah: ${ }^{9}$

1. Perjanjian yang dilarang

2. Kegiatan yang dilarang

3. Penyalahgunaan posisi dominan

4. Komisi pengawas persaingan usaha

5. Tata cara penanganan perkara

6. Sanksi-sanksi

7. Pengecualian-pengecualian

Pada 9 November 2018, PT Garuda Indonesia Tbk (Garuda), melalui anak usaha PT Citilink Indonesia, mengambil alih operasional dan finansial dari Sriwijaya Air Group (Sriwijaya) yang terdiri dari maskapai Sriwijaya dan NAM Air. Saat ini, bentuk dari pengambilalihan itu adalah adanya Kerjasama Operasi (KSO). ${ }^{10}$

Menteri Perhubungan Budi Karya Sumadi (Budi) mengaku memberi lampu hijau atas Kerja Sama Operasi (KSO) yang dilakukan PT Garuda Indonesia Tbk (Garuda) dan Sriwijaya Air Group. Budi menyatakan mendukung aksi korporasi Garuda, dan meyakini kerja sama dua maskapai itu mampu mengurangi potensi perang tarif antar maskapai penerbangan. ${ }^{11}$

PT Garuda Indonesia Tbk memastikan Kerja Sama Operasi (KSO) tidak akan mengganggu kinerja operasional Sriwijaya Air Group, justru bisa meningkatkan potensi

\footnotetext{
${ }^{8}$ Munir Fuady, SH, MH, LLM, Hukum Anti Monopoli Menyongsong Era Persaingan Sehat, (Bandung: Pt. Citra Aditya Bakti, 1999), Hal 24.

${ }^{9}$ Ibid, Hal 9.

10 Anonim, Menhub Beri Lampu Hijau Garuda Caplok Sriwijaya Air, (On-line), tersedia di: https://www.cnnindonesia.com/ekonomi/20181115164924-92-346875/menhub-beri-lampu-hijau-garuda-caploksriwijaya-air, diakses pada 26 Februari 2019.

11 Anonim, Menhub Beri Lampu Hijau Garuda Caplok Sriwijaya Air, (On-line), tersedia di: https://www.cnnindonesia.com/.., Op. Cit.
} 
kedua maskapai demi memajukan industri penerbangan. ${ }^{12}$ Namun nyatanya Indonesia National Air Carrier Association (INACA) mengakui kenaikan harga tiket pesawat sebesar 40 persen sampai 120 persen beberapa waktu terakhir. ${ }^{13}$

Komisi Pengawas Persaingan Usaha (KPPU), sebagai lembaga yang memiliki tujuan dan wewenang untuk melakukan penilaian terhadap perjanjian yang dapat mengakibatkan terjadinya praktek monopoli dan atau persaingan usaha tidak sehat sebagaimana diatur dalam Undang-undang Anti Monopoli dan Persaingan Usaha Tidak Sehat ${ }^{14}$, menaikkan status penelitian dugaan persaingan tidak sehat yang dilakukan maskapai penerbangan pelat merah PT Garuda Indonesia (Persero) dan Sriwijaya Air menjadi penyelidikan. ${ }^{15}$

Ketua Komisi Pengawas Persaingan Usaha (KPPU) Kurnia Toha menyatakan adanya dugaan kartel terkait naiknya tiket pesawat pasca KSO antara Garuda dan Sriwijaya di sepakati. ${ }^{16}$ KPPU juga menaikkan status penelitian dugaan rangkap jabatan (cross ownership) di Garuda Indonesia dan Sriwijaya menjadi penyelidikan. Hal ini diputuskan setelah KPPU melakukan serangkaian kegiatan penelitian dengan mengumpulkan keterangan dan data yang komprehensif dari pihak-pihak terkait. ${ }^{17}$ Namun yang terpenting terkait dampak dari segala indikasi kartel dan rangkap jabatan (Cross Ownership) yang dilakukan oleh kedua maskapai ini apakah sebagai penyebab semakin melonjaknya harga tiket pesawat.

12 Anonim, Garuda Jamin KSO Tak Ganggu Operasional Sriwijaya Air (On-line), tersedia di: https ://www.cnnindonesia.com/ekonomi/20181115174959-92-346904/garuda-jamin-kso-tak-ganggu-

operasional-sriwijaya-air diakses pada 26 Februari 2019.

13 Anonim, Kenaikan Harga Tiket Pesawat sempat tembus 120 persen (On-line), terseia di https://www.cnnindonesia.com/ekonomi/20190115191331-92-361065/kenaikan-harga-tiket-pesawat-s empattembus-120-persen diakses pada 1 Mei 2019.

14 Tugas dan Wewenang KPPU (On-line), tersedia di: http://www.kppu.go.id/id/tentang-kppu/tugasdan-wewenang/ diakses pada 1 Maret 2019.

15 Anonim, KPPU Selidiki Rangkap Jabatan Bos Garuda di Sriwijaya Air (On-line), tersedia di:https://www.cnnindonesia.com/ekonomi/20190212092746-92-368422/kppu-selidiki-rangkap-jabatan-bosgaruda-di-sriwijaya-air, diakses pada 26 Februari 2019.

16 Anonim, Ada Aroma Kartel dalam Kenaikan Harga Tiket Pesawat (On-Line), tersedia di: https://www.cnnindonesia.com/ekonomi/20190115125211-92-360952/ada-aroma-kartel-dalam-kenaikan-hargatiket-pesawat diakses pada 1 Mei 2019

17 Anonim, Dugaan Kartel Tiket Pesawat, Kargo, Bagasi, dan Rangkap Jabatan Naik Status (OnLine), tersedia di http://www.kppu.go.id/id/blog/2019/02/dugaan-kartel-tiket-pesawat-kargo-bagasi-danrangkap-jabatan-naik-status/ diakses pada 1 Mei 2019 


\section{B. Permasalahan}

1. Apakah Garuda dan Sriwijaya telah melakukan kartel terkait melonjaknya tarif tiket pesawat?

2. Apakah telah terjadi rangkap jabatan (Cross Ownership) yang dilakukan oleh jajaran struktural PT. Garuda Group di PT. Sriwijaya Air?

\section{Tujuan Penelitian}

Tujuan dari penelitian ini adalah untuk memahami pelaksanaan perjanjian Kerjasama Operasi (KSO) antara dua maskapai yakni PT Garuda Indonesia Tbk dan PT Sriwijaya Group dalam perspektif Hukum Anti Monopoli dan Persaingan Usaha Tidak Sehat terkait dugaan kartel dan rangkap jabatan (Cross Ownership) yang dilakukan antara PT. Garuda Indonesia Tbk dan PT. Sriwijaya Group.

\section{Metode Penelitian}

Penelitian ini adalah Penelitian hukum (legal research) yang disusun dengan menggunakan tipe penelitian yuridis normatif, yaitu penelitian yang difokuskan untuk mengkaji penerapan kaidah-kaidah atau norma-norma dalam hukum positif 18 dengan menggunakan pendekatan undang-undang (statute approach), pendekatan konseptual (conceptual approach) dan pendekatan kasus (case approach).

Metode analisis penelitian ini menggunakan bahan hukum primer berupa perundangan-undangan dan bahan hukum sekunder yang bersumber dari buku, jurnal, artikel elektronik dan situs-situs yang berhubungan dengan penerbangan dan persaingan usaha.

\section{PEMBAHASAN}

Dalam Penjelasan atas Undang-Undang Anti Monopoli No. 5 Tahun 1999, dan ditegaskan kembali dalam Pasal 3 dari Undang-Undang tersebut, bahwa UndangUndang Anti Monopoli dan Persaingan Usaha Tidak Sehat mengambil landasan kepada suatu demokrasi ekonomi berdasarkan Pancasila dan UUD 1945. Kristalisasinya adalah

18 Johnny Ibrahim, Teori dan Metodologi Penelitian Hukum Normatif, (Malang: Bayumedia Publishing, 2006), Hal. 295. 
berupa menjaga keseimbangan antara kepentingan si pelaku usaha dengan kepentingan umum, dengan tujuan untuk: ${ }^{19}$

1. Menjaga kepentingan umum dan meningkatkan efisiensi ekonomi serta melindungi konsumen.

2. Menumbuhkan iklim usaha yang kondusif melalui terciptanya persaingan usaha yang sehat, dan menjamin kepastian kesempatan berusaha yang sama bagi setiap orang.

3. Mencegah praktek-praktek monopoli dan atau persaingan usaha tidak sehat yang ditimbulkan pelaku usaha.

4. Menciptakan efektivitas dan efisiensi dalam kegiatan usaha dalam rangka meningkatkan efisiensi ekonomi nasional sebagai salah satu upaya meningkatkan kesejahteraan rakyat.

Perjanjian menurut UU Anti Monopoli dinyatakan sebagai suatu perbuatan satu atau lebih pelaku usaha untuk mengikatkan diri terhadap satu atau lebih usaha lain dengan nama apapun, baik tertulis maupun tidak tertulis. ${ }^{20}$ Kemudian lebih spesifik dirumuskan oleh Pernyataan Standar Akuntansi Keuangan (PSAK), KSO adalah perjanjian antara dua pihak atau lebih dimana masing-masing sepakat untuk melakukan suatu usaha bersama dengan menggunakan aset dan atau hak usaha yang dimiliki dan secara bersama-sama menanggung resiko usaha tersebut. ${ }^{21}$ Adapun yang menjadi penyebab dilakukannya perjanjian KSO antara Garuda dan Sriwijaya ini adalah, dinyatakan oleh Dirut PT Garuda Indonesia Tbk I Gusti Ngurah Askhara Danadiputra menyatakan Sriwijaya secara teknikal 'bangkrut'. Sriwijaya memiliki utang USD 58 juta kepada Garuda Indonesia dan sekitar Rp 1,6 triliun kepada BUMN. Dengan kondisi keuangan GIAA yang masih morat-marit, maskapai pelat merah ini akhirnya melakukan Kerja Sama Operasi (KSO) bersama Sriwijaya dalam jangka waktu 12 tahun dengan opsi pengambilalihan saham minimum 51\% dalam waktu 5 tahun. ${ }^{22}$

19 Munir fuadi, SH, MH, LL.M, Hukum Anti Monopoli Menyongsong Era Persaingan Sehat, (Bandung: PT. Citra Aditya Bakti, 1999), Hal. 2.

${ }^{20}$ Undang-Undang Republik Indonesia Nomor 5 Tahun 1999 Tentang Larangan Praktek Monopoli Dan Persaingan Usaha Tidak Sehat, Pasal 1, Butir 7.

21 Pernyataan Standar Akuntansi Keuangan Nomor 39 Tahun 2010.

22 Anonim, Garuda Akuisisi Sriwijaya (On-Line), tersedia di https://www.cnbcindonesia.com/market/20190304112633-19-58689/garuda-akuisisi-sriwijaya di akses pada 1 mei 2019 
Dalam pelaksanaan KSO tersebut Berikut hal yang menyangkut pengelolaan operasional PT Sriwijaya Air oleh Garuda Indonesia Group: ${ }^{23}$

a. Sebelum menandatangani kerja sama operasi, pada 17 Mei 2018, Garuda Indonesia Group dan PT Sriwijaya Air menandatangani kerja sama code share untuk beberapa rute penerbangan, seperti Yogyakarta-Palembang, Jakarta-Sampit, dan SemarangSampit.

b. Tujuan kerja sama operasi tersebut untuk membantu Sriwijaya Air Group memperbaiki kinerja operasi dan kinerja keuangan. KSO juga diharapkan membantu Sriwijaya Air memenuhi komitmen-komitmen atau kewajiban mereka terhadap pihak ketiga yang di antaranya ada di lingkungan Garuda Indonesia Group.

c. Dalam kerja sama operasi ini, seluruh rute penerbangan Sriwijaya akan dioperasikan oleh Citilink.

d. Kerja sama tersebut secara langsung membantu sinergi Garuda Indonesia Group dan Sriwijaya Group dalam mengelola pangsa pasar penumpang angkutan udara hingga 51 persen. Karena segmen keduanya sama, bakal terjadi efisiensi dan economic upscale.

e. Jumlah pesawat yang dimiliki PT Sriwijaya Air ada 48 Boeing (737-800 NG dan 737$900 \mathrm{ER})$.

\section{A. Indikasi Kartel Dalam Kerjasama Operasi (KSO) antara Garuda dan Sriwijaya}

Ekonom Institute for Development of Economics and Finance (INDEF), Bhima Yudhistira Adhinegara menyatakan setelah dilakukannnya KSO antara Garuda dan Sriwijaya ini tercium adanya dugaan kartel yang dilakukan oleh kedua pelaku usaha ini. Indikasi kartel ini ia jabarkan sebagai berikut: Pertama, kebijakan kenaikan dan penurunan tarif pesawat yang dilakukan secara bersama-sama oleh para maskapai. Kedua, penurunan harga yang dilakukan segera. Ketiga, struktur industri yang tidak sehat. ${ }^{24}$

23 Egy Adiyatma, Garuda Ambil Alih Operasional Sriwijaya (On-line), tersedia di https ://bisnis.tempo.co/read/1146456/5-fakta-soal-garuda-ambil-alih-operasional-sriwijaya-air/full\&view=ok diakses pada 1 Mei 2019

24 Anonim, Ada Aroma Kartel dalam Kenaikan Harga Tiket Pesawat (On-Line), tersedia di: https://www.cnnindonesia.com/.... Op. Cit 
Indikasi kartel ini tercium dari kebijakan kenaikan harga tiket pesawat kemarin. Menurutnya, jika struktur industri kuat, seharusnya ketika satu maskapai menaikkan tarif, kebijakan tersebut tidak diikuti yang lain. Satu per satu, maskapai penerbangan yang berada di luar kelompok tersebut gugur. Bhima menduga tenggelamnya maskapai tersebut tak terlepas dari persaingan bisnis tak sehat di industri ini. "Jadi perlu diselidiki, jangan-jangan memang ada strategi price fixing, sehingga pemain di industri ini kian dikit bertambahnya," imbuhnya. ${ }^{25}$

Ekonom Center of Reform on Economics (CORE) Indonesia Mohammad Faisal menilai dugaan persaingan yang tak sehat juga terlihat dari waktu maskapai memutuskan mengerek tarif. Kemarin, kenaikan tarif justru dilakukan pada musim rendah permintaan (low season). Padahal, hukum pasar biasanya momen kenaikan harga tiket dilakukan pada saat permintaan tinggi (peak season), misalnya beberapa waktu sebelum liburan akhir tahun atau jelang libur lebaran. "Artinya, memang ada indikasi kompetisi di industri yang tidak berjalan sempurna dan tidak sehat karena tidak elastis terhadap perubahan biaya produksi dan siklus permintaan pasar," jelasnya. ${ }^{26}$

Dalam Undang-undang Anti Monopoli, dijelaskan mengenai Kartel yaitu: ${ }^{27}$

"Pelaku usaha dilarang membuat perjanjian, dengan pelaku usaha saingannya, yang bermaksud mempengaruhi harga dengan mengatur produksi dan atau pemasaran suatu barang dan atau jasa, yang dapat mengakibatkan terjadinya praktek monopoli dan atau persaingan usaha tidak sehat.

Menurut Susanti Adi Nugroho dalam bukunya berjudul "Hukum Persaingan Usaha di Indonesia" disebutkan bahwa praktik kartel biasanya diprakarsai asosiasi dagang bersama para anggotanya. Yang secara terperinci ia rumuskan dalam beberapa karakteristik:28

25 Ibid,

26 Ibid,

27 Undang-Undang Republik Indonesia Nomor 5 Tahun 1999 Tentang Larangan Praktek Monopoli Dan Persaingan Usaha Tidak Sehat, Pasal 11.

28 Dr. Susanti Adi Nugroho, SH, MH, Hukum Persaingan Usaha di Indonesia, (Jakarta: Kencana Prenadamedia Gruop, 2012), Hal. 176. 
1. Terdapat konspirasi antara beberapa pelaku usaha

2. Melibatkan para senior eksekutif dari perusahaan yang terlibat

3. Biasanya dengna menggunakan asosiasi untuk menutpi kegiatan mereka

4. Melakukan price fixing atau penetapan harga. Agar penetapan harga berjalan efektif, maka diikuti dengan alokasi konsumen atau pembagian wilayah atau alokasi produksi. Biasanya kartel akan menetapkan pengurangan produksi

5. Adanya ancaman atau sanksi bagi anggota yang melanggar perjanjian. Apabila tidak ada sanksi bagi pelanggar, maka suatu kartel rentan terhadap penyelewengan untuk mendapatkan keuntungan yang lebih besar daripada anggota kartel lainnya.

6. Adanya distribusi informasi kepada seluruh anggota kartel. Bahkan jika memungkinkan dapat menyelenggarakan audit dengan menggunakan data laporan produksi dan penjualan pada periode tertentu. Auditor akan membuat laporan produksi dan penjualan setiap anggota kartel, dan kemudian membagikan hasil audit ter- sebut kepada seluruh anggota kartel.

7. Adanya mekanisme kompensasi dari anggota kartel yang pro duksinya lebih besar atau melebihi kuota terhadap mereka yan produksinya kecil, atau mereka yang diminta untuk menghentikan kegiatan usahanya. Sistem kompensasi ini tentu saja akan berhasil apabila para pelaku usaha akan mendapatkan keuntungan lebilh besar dibandingkan dengan apabila mereka melakukan persaingan. Hal ini akan membuat kepatuhan anggota kepada keputusan-keputusan kartel akan lebih terjamin. ${ }^{29}$

Meskipun, kenaikan tarif pesawat sebenarnya tidak melanggar Peraturan Menteri Perhubungan (Permenhub) Nomor 126 Tahun 2015 tentang Mekanisme Formulasi Perhitungan dan Penetapan Tarif Batas Atas dan Batas Bawah Penumpang Pelayanan Kelas Ekonomi Angkutan Udara Niaga Berjadwal Dalam Negeri. Namun, bila naik turun ini benar mengarah ke kartel, maka perlu ditindaklanjuti. Sebab, kartel tidak dibenarkan oleh Undang-undang (UU) Nomor 5 Tahun 1999 tentang Larangan Praktek Monopoli dan Persaingan Usaha Tidak Sehat.

Pedoman pelaksanaan Pasal 11 tentang Kartel merupakan petunjuk pelaksanaan untuk membuktikan dan menentukan unsur-unsur adanya kartel, yang digunakan KPPU

${ }^{29}$ Peraturan Komisi Pengawas persaingan Usaha No. 4 Tahun 2010 
untuk membuktikan unsur-unsur yang terdapat dalam Kartel berdasarkan Pasal 11 UU No. 5 Tahun 1999, yaitu:30

1. Pelaku usaha.

Pelaku usaha adalah setiap orang perorangan atau badan usaha baik yang berbentuk badan hukum maupun bukan badan hukum yang didirikan dan berkedudukan atau melakukan kegiatan dalam wilayah hukum negara Republik Indonesia, baik sendiri maupun bersama-sama melalui perjanjian, menyelenggarakan berbagai kegiatan usaha dalam bidang ekonomi. ${ }^{31}$

Pelaku usaha yang terkait dalam kartel biasanya lebih dari dua pelaku usaha, bahkan tidak jarang terjadi dalam asosiasi dagang dengan cara saling melakukan pertukaran informasi di bidang harga, pasokan roduk, maupun pembagian wilayah.

2. Perjanjian.

Pada dasarnya kartel merupakan salah satu bentuk perjanjian yang dilarang dalam UU No. 5 Tahun 1999. Bentuk perjanjian sebagaimana dimaksud dalam Pasal 1 angka 7 UU No. 5 Tahun 1999 dapat berbentuk tertulis maupun tidak tertulis. Pembuktian perjanjian tidak tertulis dapat dilakukan melalui bukti kesepakatan yang tertuang dalam agenda rapat dalam bentuk catatan maupun notula. Namun. untuk membuktikan adanva perjanjian tertulis. KPPU sering kali mengalami kesulitan memperoleh data tersebut karena pelaku usaha tidak kooperatif dan menolak memberikan data; selain itu KPPU tidak mempunyai kewenangan untuk menggeledah dan menyita dokumen yang diperlukan sebagai pembuktian.

3. Pelaku usaha pesaingnya.

Unsur pelaku usaha pesaingnya adalah pelaku usaha dalam pasar bersangkutan, di mana konsep dan pengertian pasar bersangkutan diatur berdasarkan Peraturan Komisi Pengawas Persaingan Usaha Nomor 3 Tahun 2009 mengenai Pedoman Pasal 1 angka 10 tentang Pasar Bersangkutan.

4. Bermaksud memengaruhi harga dan mengatur produksi dan/atau pemasaran barang atau jasa.

${ }^{30}$ Dr. Susanti Adi Nugroho, SH, MH, Hukum Persaingan Usaha di Indonesia..., Op.Cit., Hal. 187.

${ }^{31}$ Undang-Undang Republik Indonesia Nomor 5 Tahun 1999 Tentang Larangan Praktek Monopoli Dan Persaingan Usaha Tidak Sehat, Pasal 1, butir 5. 
Perilaku para anggota kartel untuk memengaruhi harga merupakan salah satu unsur penting yang dijadikan indikasi awal adanya kartel. Hal ini mengingat tujuan akhir pembentukan kartel adalah maksimalisasi profit dengan menetapkan harga eksesif melalui berbagai cara, misalnya membatasi kapasitas produksi dan pasokan barang sehingga harga tetap tertahan di level yang supra kompetitif. Pengaturan produksi diartikan sebagai menentukan jumlah produksi, baik bagi anggota kartel keseluruhan maupun bagi setiap anggota. Pengaturan ini bisa lebih kecil dan lebih besar dari kapasitas produksi perusahaan atau permintaan barang dan/ atau jasa yang bersangkutan. Adapun pengertian mengatur pe- masaran berarti mengatur jumlah yang akan dijual dan/atau wilayah mana para anggota menjual produksinya.

5. Mengakibatkan terjadinya praktik monopoli dan persaingan usaha tidak sehat.

Praktik yang dilakukan oleh satu atau lebih pelaku usaha, yang mengakibatkan dikuasainya produksi dan/atau pemasaran barang atau jasa tertentu menimbulkan persaingan usaha tidak sehat. Sementara unsur dapat mengakibatkan persaingan usaha tidak se- hat adalah persaingan antara pelaku usaha dalam menjalankan kegiatan produksi dan/atau pemasaran barang atau jasa dengan cara tidak jujur.

Alat bukti yang diatur dalam Pasal 42 UU No. 5 Tahun 1999 meliputi keterangan saksi, keterangan ahli, surat dan/atau dokumen, petunjuk, dan keterangan pelaku usaha. Tantangan bagi KPPU dalam pembuktian pelanggaran kartel, karena KPPU harus dapat menunjuk kan adanya bukti langsung dan bukti tidak langsung tersebut. Dalam teori hukum persaingan usaha, alat-alat bukti dalam proses investigasi kartel dapat diklasifikasikan menjadi dua jenis, yaitu: ${ }^{32}$

1) Bukti langsung

Yaitu bukti yang dapat menjelaskan adanya perjanjian atau kesepakatan tertulis atau tidak tertulis yang secara jelas menerangkan materi kesepakatan, contohnya:

a) Perjanjian tertulis, untuk menyepakati harga, mengatur produksi, mengatur pasar, membagi wilayah pemasaran, menyepakati tingkat keuntungan masingmasing

${ }^{32}$ Dr. Susanti Adi Nugroho, SH, MH, Hukum Persaingan Usaha di Indonesia..., Op. Cit,. Hal. 190. 
b) Rekaman komunikasi (baik tertulis maupun dalam bentuk elektronik) antara pelaku kartel yang menyepakati mengenai adanya suatu kolusi kartel.

c) Pernyataan lisan dan/atau tulisan yang dilakukan oleh pelaku kartel yang menyepakati kartel dibuktikan dengan rekaman catatan, atau kesaksian yang memenuhi syarat.

KPPU mendesak amendemen UU No. 5 Tahun 1999 dengan menerapkan konsep liniency program untuk membongkar praktik kartel di Indonesia. Menurut Tri Anggraini, Komisioner KPPU, Konsep liniency program adalah keistimewaan bagi pelaku usaha yang terindikasi melakukan kartel. Syaratnya, pelaku usaha tersebut bersedia membuka data dan informasi kepada KPPU mengenai kartel yang dilakukan. ${ }^{33}$ Pelaku kartel yang mengaku dan memberikan informasi ke KPPU bisa mendapat insentif atau keringanan hukuman.

2) Bukti tidak langsung, atau indirect/circumstantial evidence

Yaitu bukti yang tidak dapat menjelaskan secara terang dan spesifik mengenai materi kesepakatan antara pelaku usaha, seperti:

a) Bukti komunikasi yang membuktikan adanya komunikasi dan/atau pertemuan antarpelaku kartel, namun tidak menjelaskan mengenai substansi yang dibicarakan, contohnya:

- Rekaman komunikasi antar pesaing, bukti perjalanan menuju suatu tempat yang sama dan dalam waktu yang bersamaan antar-pesaing (rapat asosíasi), namun tidak menjelaskanu topik yang dibicarakan.

- Notula rapat yang menunjukkan pembicaraan mengenai harga, permintaan, atau kapasitas terpasang.

- Dokumen internal yang menjelaskan mengenai strategi harga pesaing.

b) Bukti ekonomi, contohnya:

- Perilaku pelaku usaha di dalam pasar atau industri secara keseluruhan, antara lain harga yang paralel; keuntungan yang tinggi; pangsa pasar yang stabil; catatan pelanggaran hukum persaingan usaha yang pernah dilakukan oleh - pelaku usaha.

33 Sutrisno Iwantono, Sulitnya membuktikan kartel di Indonesia (On-Line), tersedia di: http://iwantnco.com, di akses pada 1 Mei 2019. 
- Bukti prilaku yang memfasilitasi kartel, antara lain: pertukaran informasi, adanya signal harga, ongkos angkut yang sama; perlindungan harga, MFN (Most Favoured Nation) Policy.

- Bukti ekonomi struktural, antara lain: tingkat konsentrasi industri yang tinggi; konsentrasi yang rendah pada industri lawannya; tingginya hambatan masuk, banyaknya integrasi vertikal, produk yang homogen. ${ }^{34}$ Dalam hal bukti-bukti tidak langsung yang diungkapkan hanya sedikit tanpa disertai uji ataupun analisis yang tepat, maka tentu saja pembuktian mengenai pelanggaran kartel menjadi tidak valid. Pengaturan indirect evidence, didasari pertimbangan bahwa memang sulit memperoleh bukti langsung dari praktik kartel.

Di luar dugaan kartel, pengamat penerbangan Alvin Lie menilai kenaikan tarif pesawat sebenarnya diperlukan oleh maskapai karena kondisi keuangan mereka sudah berdarah-darah. Hal ini terjadi karena persaingan bisnis dalam beberapa waktu terakhir membuat para maskapai terpaksa banting-bantingan harga. Menurutnya, indikasi maskapai berdarah-darah terlihat jelas dari beban keuangan yang dihadapi Garuda Indonesia. Maskapai pelat merah itu sudah langganan menderita kerugian dalam beberapa tahun terakhir, bahkan sampai menjadi sorotan publik. ${ }^{35}$

Berdasarkan laporan keuangan per kuartal III 2018, setidaknya perseroan (Garuda) masih merugi sekitar US\$114,08 juta setara Rp1,66 triliun (kurs Rp14.600 per dolar AS). Indikasi lain, tercermin dari aksi merapatnya Sriwijaya Air ke Garuda Indonesia. Maskapai milik Chandra Lie itu akhirnya memilih bergabung ke maskapai BUMN (Garuda) karena memiliki utang sekitar Rp433 miliar yang harus dilunasi ke PT Garuda Maintanance Facility Aeroasia (GMFAA), anak usaha Garuda Indonesia. Utang itu terdiri dari utang pemeriksaan menyeluruh (overhaul) 10 mesin pesawat sebesar US\$9,33 juta atau sekitar Rp139,3 miliar (kurs Rp14.929 per dolar AS). Lalu, utang perawatan pesawat sebesar US\$6,28 juta atau sekitar Rp92,75 miliar dan Rp119,77 miliar yang telah dianjak piutang kepada PT Bank Negara Indonesia Tbk (BNI). ${ }^{36}$

\footnotetext{
${ }^{34}$ Sutrisno Iwantono, Sulitnya Membuktikan Kartel di Indonesia,, Op. Cit.

35 Anonim, Ada Aroma Kartel dalam Kenaikan Harga Tiket Pesawat (On-Line), tersedia di:
} https://www.cnnindonesia.com/ekonomi/201901 15125211-92-360952/ada-aro ma-kartel-dalam-kenaikan-hargatiket-pesawat diakses pada 1 Mei 2019.

36 Ibid, 
Lebih lanjut, Alvin menilai sekalipun maskapai mengerek harga seperti yang dilakukan beberapa waktu lalu. Toh, tarif penerbangan yang dipasang sejatinya tidak melanggar ketentuan aturan tarif batas atas dari pemerintah. Artinya, lagi-lagi maskapai tetap berusaha menjaga daya beli masyarakat. ${ }^{37}$

\section{B. Rangkap Jabatan Direksi Garuda dalam Struktural Sriwijaya}

Pasca KSO antara Garuda dan Srwijaya, Sesuai dengan hasil Rapat Umum Pemegang Saham (RUPS) Sriwijaya Air, telah diputuskan beberapa wajah baru dalam direktorat Sriwijaya Air, yaitu:38

Dewan Komisaris Sriwijaya Air:

Komisaris Utama

Wakil Komisaris Utama

Komisaris

Komisaris

Komisaris

Komisaris

Komisaris
: I Gusti Ngurah Askhara Danadiputra

: Chandra Lie

: Pikri Ilham Kurniansyah

: Juliandra Nurtjahtjo

: Hendri Lie

: Sonia Xevianne Bonggoro

: Jefferson Irwin Jauwena

Dewan Direksi Sriwijaya Air:

Direktur Utama

Direktur Niaga

Direktur Human Capital

Direktur Keuangan

Direktur Operasi

Direktur Quality, Safety \& Security : Capt Toto Soebandoro

Direktur Teknik
: Joseph Adriaan Saul

: Joseph Dajoe K. Tendean

: Harkandri M. Dahler

: Amrulloh Hakiem

: Capt Fajar Semiarto Jaja
: Capt Toto Soebandoro
: Romdani Ardali Adang

Komisioner KPPU, Guntur Syahputra Saragih menyatakan saat ini, direksi Garuda Indonesia (I Gusti Ngurah Askhara Danadiputra) seharusnya tidak bisa menempati posisi sejenis di Sriwijaya karena perusahaan tersebut belum melakukan merger. ${ }^{39}$

${ }^{37}$ Anonim, Alvin Lie: Harga Tiket Naik bukan Mainan Kartel (On-Line), tersedia di: https://beritagar.id/artikel/berita/alvin-lie-harga-tiket-naik-bukan-mainan-kartel diakses pada 1 Mei 2019

38 Anonim, Dewan Komisaris dan Dewan Direksi Sriwijaya Air (On-line), tersedia di” https://www.airmagz.com/35523/ini-dewan-komisaris-dan-dewan-direksi-sriwijaya-air-yang-baru.html diakses pada 1 Mei 2019.

39 Anonim, KPPU Selidiki Rangkap Jabatan Bos Garuda di Sriwijaya Air (On-Line), tersedia di: https://www.cnnindonesia.com/ekonomi/20190212092746-92-368422/kppu-selidiki-rangkap-jabatan-bos-

garuda-di-sriwijaya-air diakses pada 1 Mei 2019. 
Direksi atau anggota Direksi (dikarenakan Undang-Undang No. 40 Tahun 2007 tentang Perseroan Terbatas ("UUPT") tidak mengenal istilahdirektur utama) pada dasarnya tidak mengatur mengenai rangkap jabatan. Hal ini terlihat dari Pasal 93 ayat (1) UUPT, yang mengatakan bahwa yang dapat diangkat menjadi anggota Direksi adalah orang perseorangan yang cakap melakukan perbuatan hukum, kecuali dalam waktu 5 (lima) tahun sebelum pengangkatannya pernah:

a. Dinyatakan pailit;

b. Menjadi anggota Direksi atau anggota Dewan Komisaris yang dinyatakan bersalah menyebabkan suatu Perseroan dinyatakan pailit; atau

c. Dihukum karena melakukan tindak pidana yang merugikan keuangan negara dan/atau yang berkaitan dengan sektor keuangan.

Akan tetapi sebagaimana disebutkan dalam Pasal 93 ayat (2) UUPT bahwa persyaratan dalamPasal 93 ayat (1) UUPT tidak mengurangi kemungkinan instansi teknis yang berwenang menetapkan persyaratan tambahan berdasarkan peraturan perundang-undangan. tetapi mendefinikan Peraturan Undang-undang Anti Monopoli terkait rangkap jabatan yaitu :

"Seseorang yang menduduki jabatan sebagai Direksi atau Komisaris dari suatu perusahaan, pada waktu yang bersamaan dilarang merangkap menjadi Direksi atau Komisaris pada perusahaan lain, apabila perusahaan tersebut:

a. Berada dalam pasar bersangkutan yang sama; atau

b. Memiliki keterkaitan yang erat dalam bidang dan atau jenis usaha; atau

c. Secara bersama dapat menguasai pangsa pasar barang dan atau jasa tertentu, yang dapat mengakibatkan terjadinya praktek monopoli dan atau persaingan usaha tidak sehat."

Penjabaran unsur-unsur yang ada dalam ketentuan Pasal 26 UU No. 5 Tahun 1999 adalah sebagai berikut: ${ }^{40}$

\section{Seseorang}

Penyebutan seseorang dalam perumusan Pasal 26 UU No. 5 Tahun 1999 adalah menegaskan bahwa hanya individu perorangan, dan tidak termasuk badan hukum, yang berhak dan dapat diangkat sebagai anggota Direksi atau Komisaris perusahaan sesuai dengan peraturan perundang-undangan yang berlaku.

\footnotetext{
${ }^{40}$ Lampiran Peraturan Komisi Pengawas Persaingan Usaha Nomor 7 Tahun 2010 Tentang Pedoman Jabatan Rangkap sesuaiketentuan Pasal 26 Undang-Undang Nomor 5 Tahun 1999 Tentang Larangan Praktek Monopoli Dan Persaingan Usaha Tidak Sehat.
} 


\section{Direksi}

Sesuai dengan Pasal 1 angka 4. UU No. 1 Tahun 1995, Direksi adalah badan suatu perusahaan, yang bertanggung jawab penuh atas pengelolaan perusahaan bersangkutan demi kepentingan dan tujuan yang dianut perusahaan tersebut dan yang mewakili perusahaan baik di dalam maupun di luar pengadilan sesuai dengan ketentuan Anggaran Dasar.

\section{Komisaris}

Sesuai dengan Pasal 1 angka 5. UU No. 1 Tahun 1995, Komisaris suatu badan perusahaan, yang ditugaskan dengan kewajiban untuk melakukan pengawasan, baik secara umum maupun khusus dan menasihati Dewan Direksi dalam menjalankan perusahaan.

4. Waktu yang bersamaan

Waktu yang bersamaan adalah saat dimana seseorang secara sah menduduki 2 (dua) atau lebih jabatan sebagai direksi atau komisaris dalam 1 (satu) atau lebih perusahaan lain.

5. Perusahaan

Perusahaan adalah setiap bentuk usaha yang menjalankan setiap jenis usaha yang bersifat tetap dan terus menerus dan yang didirikan, bekerja, serta berkedudukan dalam wilayah Negara RI, untuk tujuan memperoleh keuntungan dan atau laba, termasuk juga perusahaan-perusahaan yang dimiliki oleh atau bernaung di bawah lembaga-lembaga sosial.

6. Pasar Bersangkutan

Sebagaimana dimaksud pada Pasal 1 butir 10. UU No. 5 Tahun 1999 Pasar Bersangkutan adalah Pasar yang berkaitan dengan jangkauan atau daerah pemasaran tertentu oleh pelaku usaha atau jasa yang sama atau sejenis atau subsitusi dari barang dan atau jasa. Pengertian pasar bersangkutan juga meliputi pasar produk dan pasar wilayah.

7. Adanya Keterkaitan Erat Dalam Bidang dan atau Jenis Usaha.

Sebagaimana yang dimaksud dalam penjelasan Pasal 26 huruf (b). UU No. 5 Tahun 1999 Perusahaan-perusahaan memiliki keterkaitan yang erat bila perusahaan 
perusahaan tersebut saling mendukung atau berhubungan langsung dalam proses produksi, pemasaran, atau produksi dan pemasaran. Ketentuan ini tidak hanya diterapkan terhadap jabatan rangkap direksi yang horizontal tetapi juga jabatan rangkap yang melibatkan direksi perusahaan produsen dan pemasoknya.

\section{Menguasai}

Menggunakan penafsiran sistematis, pengertian menguasai dapat ditafsirkan sebagai posisi dominan sesuai Pasal 1 ayat 4. UU No. 5 Tahun 1999 yaitu "Keadaan dimana pelaku usaha tidak mempunyai pesaing yang berarti di pasar yang bersangkutan dalam kaitan dengan pangsa pasar yang dikuasai, atau pelaku usaha mempunyai posisi tertinggi di antara pesaingnya di pasar bersangkutan dalam kaitan dengan kemampuan keuangan, kemampuan akses pada pasokan atau penjualan, serta kemampuan untuk menyesuaikan pasokan atau permintaan barang atau jasa tertentu." Pelaku usaha atau perusahaan memiliki posisi dominan apabila memenuhi ketentuan Pasal 25 ayat (2) UU No. 5 Tahun 1999.

\section{Pangsa pasar}

Pangsa pasar sebagaimana dimaksud dalam Pasal 1 angka 13. UU No 5

Tahun 1999 adalah persentase nilai jual atau beli barang atau jasa tertentu yang dikuasai oleh pelaku usaha pada pasar bersangkutan dalam tahun kalender tertentu.

10. Barang

Pengertian barang sebagaimana dimaksud dalam Pasal 1 angka 16. UU No. 5 Tahun 1999 adalah setiap benda, baik berwujud maupun tidak berwujud, baik bergerak maupun tidak bergerak, yang dapat diperdagangkan, dipakai, dipergunakan, atau dimanfaatkan oleh konsumen atau pelaku usaha.

11. Jasa

Jasa sebagaimana dimaksud dalam Pasal 1 angka 17. UU No. 5 Tahun 1999 adalah setiap layanan yang berbentuk pekerjaan atau prestasi yang diperdagangkan dalam masyarakat untuk dimanfaatkan oleh konsumen atau pelaku usaha.

12. Mengakibatkan Praktek Monopoli

Sebagaimana yang dimaksud dalam Pasal 1 butir 2. UU No. 5 Tahun 1999 Praktek monopoli adalah pemusatan kekuatan ekonomi oleh satu atau lebih pelaku 
usaha yang mengakibatkan dikuasainya produksi dan atau pemasaran atas barang dan atau jasa tertentu sehingga menimbulkan persaingan usaha tidak sehat dan dapat merugikan kepentingan umum.

\section{Persaingan Usaha Tidak Sehat}

Sebagaimana yang dimaksud dalam Pasal 1 butir 6. UU No. 5 Tahun 1999 Persaingan Usaha Tidak Sehat adalah persaiangan antar pelaku usaha dalam menjalankan kegiatan produksi, dan atau pemasaran barang dan atau jasa yang dilakukan dengan cara tidak jujur atau melawan hukum atau menghambat persaingan usaha.

Adapun praktik rangkap jabatan yang disinyalir dapat mendorong terjadinya penguasaan pasar ini dianggap bertentangan dengan Undang-undang Nomor 5 Tahun 1999 tentang Larangan Monopoli dan Praktek Persaingan Usaha Tidak Sehat. Pasal 26 Undang-undang tersebut menyatakan bahwa seseorang yang menempati jabatan sebagai direksi atau komisaris dari suatu perusahaan dilarang merangkap jabatan yang sama bila ia berada dalam pasar sejenis pada waktu yang ber samaan.

Terhadap larangan rangkap jabatan menurut Pasal 26 diatas, dalam UU Persaingan Usaha juga mengatur mengenai ketentuan sanksinya. Seperti terdapat dalam Pasal 47 UU Anti Monopoli, KPPU berwenang menjatuhkan sanksi administratif terhadap pelaku usaha yang melanggar ketentuan Pasal 26, antara lain berupa:

1. Perintah kepada pelaku usaha untuk menghentikan kegiatan yang terbukti menimbulkan praktek monopoli dan atau persaingan usaha tidak sehat dan atau merugikan masyarakat (Pasal 47 ayat (2) butir c); dan/atau;

2. Penetapan pembayaran ganti rugi (Pasal 47 ayat (2) butir f); dan/atau;

3. Pengenaan denda dalam jumlah antara Rp. 1.000.000.000, 00 (satu milyar rupiah) dan setinggi-tingginya Rp. 25.000.000.000,00 (dua puluh lima milyar Rupiah) (Pasal 47 (2) butir g).

Terhadap pelanggaran Pasal 26 juga dapat dikenakan hukuman pidana pokok sebagaimana diatur dalam Pasal 48 UU Anti Monopoli berupa:

1. Pidana denda serendah-rendahnya Rp.5.000.000.000,00 (lima milyar Rupiah) dan setinggi-tingginya Rp.25.000.000.000,00 (dua puluh milyar Rupiah), atau pidana kurungan pengganti denda selama lamanya 5 (lima) bulan (Pasal 48 ayat (2)). 
2. Pidana denda serendah-rendahnya Rp.1.000.000.000,00 (satu milyar Rupiah) dan setinggi-tingginya Rp.5.000.000.000,00 (lima milyar Rupiah), atau pidana kurungan pengganti denda selama-lamanya 3 (tiga) bulan (Pasal 48 ayat (3)), dalam hal pelaku usaha dan/atau menolak menyerahkan alat bukti yang diperlukan dalam penyelidikan dan/atau pemeriksaan atau menolak diperiksa, menolak memberikan informasi yang diperlukan dalam penyelidikan dan/atau pemeriksaan, atau menghambat proses penyelidikan dan/atau pemeriksaan sebagaimana dimaksud dalam Pasal 41 ayat (1) dan (2).

Selain pidana pokok tersebut, untuk pelanggaran terhadap Pasal 26 dapat juga dijatuhkan pidana tambahan sebagaimana diatur dalam Pasal 49 UU Anti Monopoli berupa:

1. Pencabutan izin usaha; atau

2. Larangan kepada pelaku usaha yang telah terbukti melakukan pelanggaran terhadap UU No.5/1999 untuk menduduki jabatan Direksi atau Komisaris antara 2 (dua) tahun sampai dengan 5 (lima) tahun; atau

3. Penghentian kegiatan atau tindakan tertentu yang menyebabkan timbulnya kerugian pada pihak lain.

\section{PENUTUP}

\section{A. Kesimpulan}

Dari pemaparan Jurnal ini, penulis merangkum kesimpulan, sebagai berikut:

1. Perjanjian KSO yang dilakukan PT. Garuda Indonesia Group (Garuda) dan PT. Sriwijaya Air (Sriwijaya) pada 9 November 2018 didasari atas hutang yang dimiliki oleh Sriwijaya kepada Garuda Group. Dalam perjanjian ini Garuda mengambilalih operational Sriwijaya Air dalam jangka waktu 12 tahun dengan opsi pengambilalihan saham minimum 51\% dalam waktu 5 tahun. Namun yang dirasakan oleh masyarakat pasca KSO tersebut adanya kenaikan harga yang signifikan, sehingga memicu kecurigaan Kartel. Memang terdapat karakteristik Kartel dalam perjanjian ini, namun setelah KPPU memanggil kedua pelaku usaha, ternyata tuntutan operasionallah yang memaksa maskapai menaikan harga tarif tiket pesawat. Kenyataannya, bahwa harga tiket pesawat yang ditetapkan kedua maskapai ini tidak melewati batas maksimim harga tiket pesawat yang ditetapkan oleh pemerintah.

2. Adanya indikasi rangkap jabatan yang dilakukan oleh Garuda dan Sriwijaya adalah sebuah fakta bahwa Direktur Utama Garuda, Ari Aksara, merangkap sebagai 
Komisari Sriwijaya pasca KSO yang dilakukan antara kedua maskapai. KPPU telah memanggil kedua maskapai dan sampai saat ini belum ada publikasi maupun tindak lanjut dari pemanggilan tersebut.

\section{Saran}

Dari pemaparan Jurnal ini, penulis memberikan saran yaitu

1. Pemerintah hendaknya memberikan batas maksimim dan minimum tarif yang memang sesuai dengan daya beli masyarakat. Kenaikan harga tarif tiket pesawat dalam kasus ini nyatanya masih dalam batasan yang ditetapkan pemerintah. Pemerintah hendaknya melakukan polling terbuka masalah penetapan tarif ini kepada masyarakat.

2. Adanya koordinasi yang yang sinergis antara Pemerintah, Perusahaan Penerb angan dan Perusahaan Penyedia bahan bakar, dikarenakan faktor yang menjadi kenaikan harga tiket pesawat adalah tingginya biaya operasional maskapai yang didominasi oleh harga avtur. Ditakutkan dengan posisi maskapai yang serba salah ini akan memicu bergugurnya ketahanan maskapai untuk bersaing dalam industri penerbangan sipil. 


\section{DAFTAR PUSTAKA}

$\underline{\text { Buku }}$

Dr. Susanti Adi Nugroho, SH, MH, Hukum Persaingan Usaha di Indonesia. Jakarta:

Kencana Prenadamedia Gruop, 2012.

Mohammad Hatta, Pengertian Pancasila. Jakarta: Idayu, 1981.

Munir Fuady, SH, MH, LLM, Hukum Anti Monopoli Menyongsong Era Persaingan Sehat. Bandung: Pt. Citra Aditya Bakti, 1999.

Johnny Ibrahim, Teori dan Metodologi Penelitian Hukum Normatif. Malang: Bayumedia Publishing, 2006.

\section{Perundang-undangan}

Peraturan Komisi Pengawas persaingan Usaha No. 4 Tahun 2010

Pernyataan Standar Akuntansi Keuangan Nomor 39 Tahun 2010

Republik Indonesia, Undang-Undang Dasar Republik Indonesia 1945 dan Perubahannya. Undang-Undang Republik Indonesia Nomor 5 Tahun 1999 Tentang Larangan Praktek Monopoli Dan Persaingan Usaha Tidak Sehat.

Undang-Undang No. 40 Tahun 2007 tentang Perseroan Terbatas

Departemen Perhubungan R.I. (2005). Cetak Biru Transportasi Udara 2005-2024. Direktorat Jenderal Perhubungan Udara, Jakarta

Lampiran Peraturan Komisi Pengawas Persaingan Usaha Nomor 7 Tahun 2010 Tentang Pedoman Jabatan Rangkap sesuai ketentuan Pasal 26 Undang-Undang Nomor 5 Sehat.

Tahun 1999 Tentang Larangan Praktek Monopoli Dan Persaingan Usaha Tidak

Jurnal

Warta Ardhia, "Perkembangan Perekonomian Wilayah dan Kargo Udara: Korelasi atau Kausalitas?" Jurnal Pusat Litbang Perhubungan Udara Vol. 41 No. 1 hal. 39-48 (2015).

Internet

Anonim, Pertumbuhan Sektor Transportasi Udara Cerminkan Ekonomi Nasional (OnLine), tersedia

di: https://www.suaramerdeka.com/news/baca/24547/pertumbuhan-sektor transportasi-udara-cerminkan-ekonomi-nasional.

Anonim, Menhub Beri Lampu Hijau Garuda Caplok Sriwijaya Air, (On-line), tersedia di: https://www.cnnindonesia.com/ekonomi/20181115164924-92-

346875/menhub- beri-lampu-hijau-garuda-caplok-sriwijaya-air. 
Anonim, Garuda Jamin KSO Tak Ganggu Operasional Sriwijaya Air (On-line), tersedia di: https://www.cnnindonesia.com/ekonomi/20181115174959-92-

346904/garuda-jamin-kso-tak-ganggu- operasional-sriwijaya-air

Anonim, Kenaikan Harga Tiket Pesawat sempat tembus 120 persen (On-line), terseia di https://www.cnnindonesia.com/ekonomi/20190115191331-92-

361065/kenaikan- harga-tiket-pesawat-sempat-tembus-120-persen

Anonim, KPPU Selidiki Rangkap Jabatan Bos Garuda di Sriwijaya Air (On-line), tersedia di:

https://www.cnnindonesia.com/ekonomi/20190212092746-92-368422/kppuselidiki-rangkap-jabatan-bos-garuda-di-sriwijaya-air,

Anonim, Ada Aroma Kartel dalam Kenaikan Harga Tiket Pesawat (On-Line), tersedia di: https://www.cnnindonesia.com/ekonomi/20190115125211-92-360952/adaaroma-kartel-dalam-kenaikan-harga-tiket-pesawat

Anonim, Dugaan Kartel Tiket Pesawat, Kargo, Bagasi, dan Rangkap Jabatan Naik Status (On-Line), tersedia di http://www.kppu.go.id/id/blog/2019/02/dugaankartel-tiket-pesawat-kargo-bagasi-dan-rangkap-jabatan-naik-status/

Anonim, Garuda Akuisisi Sriwijaya (On-Line), tersedia di https://www.cnbcindonesia.com/market/20190304112633-19-58689/garudaakuisisi-sriwijaya

Anonim, Tiket Kompak Naik Turun Apakah Maskapai Penerbangan Kartel? (On-Line), tersedia di: https://tirto.id/tiket-kompak-naik-turun-apakah-maskapaipenerbangan-kartel-derF

Anonim, Dewan Komisaris dan Dewan Direksi Sriwijaya Air (On-line), tersedia di" https://www.airmagz.com/35523/ini-dewan-komisaris-dan-dewan-direksi-

sriwijaya- air-yang-baru.html

Anonim, KPPU Selidiki Rangkap Jabatan Bos Garuda di Sriwijaya Air (On-Line), tersedia di: https://www.cnnindonesia.com/ekonomi/20190212092746-92368422/kppu-selidiki-rangkap-jabatan-bos-garuda-di-sriwijaya-air

Anonim, Alvin Lie: Harga Tiket Naik bukan Mainan Kartel (On-Line), tersedia di: https://beritagar.id/artikel/berita/alvin-lie-harga-tiket-naik-bukan-mainan-

kartel

Egy Adiyatma, Garuda Ambil Alih Operasional Sriwijaya (On-line), tersedia di https://bisnis.tempo.co/read/1146456/5-fakta-soal-garuda-ambil-alihoperasional-sriwijaya-air/full\&view=ok

Tugas dan Wewenang KPPU (On-line), tersedia di: http://www.kppu.go.id/id/tentang$\mathrm{kppu}$ /tugas-dan-wewenang/ 